\title{
Bacillus galliciensis sp. nov., isolated from faeces of wild seahorses (Hippocampus guttulatus)
}

\author{
José Luis Balcázar, José Pintado and Miquel Planas \\ Instituto de Investigaciones Marinas, Consejo Superior de Investigaciones Científicas (CSIC), \\ c/. Eduardo Cabello 6, 36208 Vigo, Spain
}

Correspondence

José Luis Balcázar

balcazar@iim.csic.e

\begin{abstract}
A Gram-positive-staining, motile, rod-shaped, endospore-forming bacterium (BFLP-1 ${ }^{\top}$ ) was isolated from faeces of wild long-snouted seahorses (Hippocampus guttulatus) captured in northwest Spain (Toralla, Galicia). Strain BFLP- $1^{\top}$ grew at $10-30{ }^{\circ} \mathrm{C}$ and $\mathrm{pH} 5.5-9$ (optimally at $20{ }^{\circ} \mathrm{C}$ and $\left.\mathrm{pH} 7.2\right)$ and with $0-7 \%(\mathrm{w} / \mathrm{v}) \mathrm{NaCl}$ (optimally with $2 \% \mathrm{NaCl}$ ). The $\mathrm{G}+\mathrm{C}$ content of the DNA was $48.1 \mathrm{~mol} \%$. Phylogenetic analysis based on 16S rRNA gene sequences showed that strain BFLP $-1^{\top}$ was a member of the genus Bacillus and was most closely related to Bacillus herbersteinensis D-1,5a ${ }^{\top}(96.6 \%)$, B. shackletonii LMG $18435^{\top}(96.0 \%)$ and $B$. isabeliae CVS$8^{\top}$ (95.9\%). Chemotaxonomic data (peptidoglycan type, meso-diaminopimelic acid; major menaquinone, MK-7; predominant fatty acids, anteiso- $C_{15: 0}$, anteiso- $C_{17: 0}$ and $C_{16: 1} \omega 11 c$; major polar lipids, diphosphatidylglycerol, phosphatidylglycerol, phosphatidylethanolamine and an unknown aminoglycophospholipid) supported the affiliation of strain BFLP-1 ${ }^{\top}$ to the genus Bacillus. Comparative analysis of $16 \mathrm{~S}$ rRNA gene sequences and chemotaxonomic and phenotypic features indicated that strain BFLP-1 ${ }^{\top}$ represents a novel species within the genus Bacillus, for which the name Bacillus galliciensis sp. nov. is proposed. The type strain is BFLP-1 ${ }^{\top}$

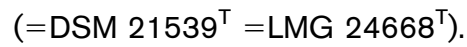

The genus Bacillus is an extensive, heterogeneous group, with members exhibiting a wide range of physiological and genetic characteristics (Ash et al., 1991; Rössler et al., 1991; Xu \& Côté, 2003). Bacilli can occupy a wide variety of ecological niches including soil, water and some clinical samples (Logan et al., 2004; Wieser et al., 2005; Albuquerque et al., 2008). Members of the genus also produce antibiotics, enzymes and other metabolites that are used extensively in the medical and pharmaceutical industries (Banat et al., 2000; Balcázar \& Rojas-Luna, 2007; Sorokulova et al., 2008).

During the characterization of organisms isolated from faeces of wild long-snouted seahorses (Hippocampus guttulatus), strain BFLP- $1^{\mathrm{T}}$ was grown on tryptone soy agar (TSA) supplemented with $1.5 \%(\mathrm{w} / \mathrm{v}) \mathrm{NaCl}$ at $20{ }^{\circ} \mathrm{C}$ for $72 \mathrm{~h}$. Subcultivation was done on the same medium at $20{ }^{\circ} \mathrm{C}$ for $48 \mathrm{~h}$. On this agar, BFLP- $1^{\mathrm{T}}$ was able to grow at 10-30 ${ }^{\circ} \mathrm{C}$, but not at 5 or $35{ }^{\circ} \mathrm{C}$.

The Gram reaction was determined using the non-staining (KOH) method as described by Buck (1982). Cell morphology and motility were studied using phase-contrast

The GenBank/EMBL/DDBJ accession number for the 16S rRNA gene sequence of strain BFLP-1 $1^{\top}$ is FM162181.

A maximum-parsimony phylogenetic tree based on 16S rRNA gene sequences is available as supplementary material with the online version of this paper. microscopy. $\mathrm{NaCl}$ tolerance and requirement for growth were investigated by using nutrient broth $(0.5 \%$ peptone from casein, $0.3 \%$ meat extract, $0.3 \%$ yeast extract; $\mathrm{pH}$ 7.2) supplemented with various concentrations of $\mathrm{NaCl}(0-15 \%$ at intervals of $1 \%)$. The $\mathrm{pH}$ range for growth was determined in nutrient broth adjusted to $\mathrm{pH} 2.0-12.5$ at intervals of $0.5 \mathrm{pH}$ units. Anaerobic growth was assessed at $20{ }^{\circ} \mathrm{C}$ in an anaerobic chamber with a $\mathrm{H}_{2}$ / $\mathrm{CO}_{2}$ atmosphere (bioMérieux).

Catalase activity was determined by assessing bubble production in $3 \%(\mathrm{v} / \mathrm{v}) \mathrm{H}_{2} \mathrm{O}_{2}$; oxidase activity was determined using $1 \%(\mathrm{w} / \mathrm{v})$ tetramethyl-p-phenylenediamine as described by Lim et al. (2008). Some physiological characteristics were performed using API 20NE and API 20A strips (bioMérieux). Cells for inoculation of the strips were grown for $24 \mathrm{~h}$ at $20{ }^{\circ} \mathrm{C}$ on TSA and results were interpreted visually, according to the manufacturer's instructions.

Strain BFLP $-1^{\mathrm{T}}$ was found to consist of Gram-positivestaining, aerobic, motile, rod-shaped cells. Colonies on TSA were circular to slightly irregular and cream in colour after incubation at $20{ }^{\circ} \mathrm{C}$ for $48 \mathrm{~h}$. The strain grew with 0 $7 \%(\mathrm{w} / \mathrm{v}) \mathrm{NaCl}$ (optimum $2 \%$ ), but not with $8.0 \% \mathrm{NaCl}$. Growth was observed at $\mathrm{pH}$ 5.5-9.0 (optimum $\mathrm{pH}$ 7.2). Oxidase and catalase reactions were positive. Other physiological characteristics of strain BFLP- ${ }^{\mathrm{T}}$ are shown in Table 1 and in the species description. 
Table 1. Characteristics of strain BFLP-1 ${ }^{\top}$ and the type strains of some related Bacillus species

Strains: 1 , Bacillus galliciensis sp. nov. BFLP-1 ${ }^{\mathrm{T}} ; 2$, B. herbersteinensis $\mathrm{D}-1,5 \mathrm{a}^{\mathrm{T}} ; 3$, B. shackletonii $\mathrm{LMG} 18435^{\mathrm{T}} ; 4$, B. isabeliae CVS-8 ${ }^{\mathrm{T}}$. All data were obtained in this study. + , Positive; $(+)$, weakly positive; - , negative.

\begin{tabular}{|c|c|c|c|c|}
\hline Characteristic & 1 & 2 & 3 & 4 \\
\hline Sporangium shape & Swollen & Unswollen & Swollen & Swollen \\
\hline \multicolumn{5}{|l|}{ Conditions for growth } \\
\hline $\mathrm{NaCl}(\% \mathrm{w} / \mathrm{v})$ & $0-7$ & $0-5$ & $0-3$ & $1-14$ \\
\hline Temperature $\left({ }^{\circ} \mathrm{C}\right)$ & $10-30$ & $4-28$ & $15-55$ & $20-40$ \\
\hline Assimilation of $\mathrm{N}$-acetylglucosamine & + & + & + & - \\
\hline Cellobiose & - & - & + & + \\
\hline D-Glucose & - & - & + & - \\
\hline Lactose & - & - & $(+)$ & - \\
\hline Maltose & - & - & $(+)$ & - \\
\hline D-Mannitol & - & - & $(+)$ & - \\
\hline D-Mannose & - & - & $(+)$ & - \\
\hline D-Xylose & - & - & - & $(+)$ \\
\hline Major fatty acids ${ }^{\star}$ & $\begin{array}{c}\text { ai- } C_{15: 0}, \text { ai- } C_{17: 0} \\
C_{16: 1} \omega 11 c\end{array}$ & ai- $C_{15: 0}, \mathrm{i}-\mathrm{C}_{15: 0}$ & $\begin{array}{l}\text { ai- } C_{15: 0}, \mathrm{i}-\mathrm{C}_{15: 0} \\
\mathrm{i}-\mathrm{C}_{16: 0}, \text { ai- } \mathrm{C}_{17: 0}\end{array}$ & $\begin{array}{l}\text { i- } C_{15: 0}, \text { ai- } C_{15: 0}, \\
\quad \text { i- } C_{16: 0}, C_{16: 0}\end{array}$ \\
\hline
\end{tabular}

*ai, Anteiso-branched; i, iso-branched.

For base composition analysis, DNA was prepared according to Chun \& Goodfellow (1995) and the G+C content was determined by the thermal denaturation method (Mandel \& Marmur, 1968). DNA from Bacillus subtilis subsp. subtilis DSM $10^{\mathrm{T}}$ was used as the reference for determination of the thermal-melting profile $\left(T_{\mathrm{m}}\right)$. The DNA G + C content was calculated to be $48.1 \mathrm{~mol} \%$. This value is within the range for the genus Bacillus (Xue et al., 2008).

The 16S rRNA gene sequence was amplified by PCR with the universal primers 27F ( $5^{\prime}$-AGAGTTTGATCCTGGCTCAG-3') and 1492R (5'-GGTTACCTTGTTACGACTT- $3^{\prime}$ ). Amplification was carried out with a DNA thermal cycler (GeneAmp PCR System 2700; Applied Biosystems) according to the following program: $95{ }^{\circ} \mathrm{C}$ for $10 \mathrm{~min}, 30$ cycles of $94{ }^{\circ} \mathrm{C}$ for $0.5 \mathrm{~min}, 50{ }^{\circ} \mathrm{C}$ for $1 \mathrm{~min}$ and $72{ }^{\circ} \mathrm{C}$ for $2 \mathrm{~min}$ and final extension at $72{ }^{\circ} \mathrm{C}$ for $10 \mathrm{~min}$. PCR products were purified by using ExoSAP-IT (USB). Sequencing was performed using the BigDye Terminator Cycle Sequencing Ready Reaction kit with an ABI PRISM 377 Genetic Analyzer (Applied Biosystems), according to the manufacturer's instructions, and five primers $(337 \mathrm{~F}, 785 \mathrm{~F}, 1225 \mathrm{~F}$, $518 \mathrm{R}, 1100 \mathrm{R})$. The consensus sequences obtained were compared with reference 16S rRNA gene sequences available in the GenBank databases using BLASTN (Altschul et al., 1990). After multiple alignments of data by CLUSTAL_X (Thompson et al., 1997), phylogenetic analysis was performed using MEGA version 4.0 (Tamura et al., 2007) with distances calculated according to the Kimura-2 model and the neighbour-joining and maximum-parsimony methods. Bootstrap calculations were based on 1000 replications. The 16S rRNA gene sequence of strain BFLP- ${ }^{\mathrm{T}}$ was a continuous stretch of $1490 \mathrm{bp}$. The neighbour-joining analysis (Fig. 1) indicated that the closest relatives of strain BFLP $-1^{\mathrm{T}}$ were Bacillus herbersteinensis $\mathrm{D}-1,5 \mathrm{a}^{\mathrm{T}}$ (96.6\%), B. shackletonii $\mathrm{LMG} 18435^{\mathrm{T}}(96.0 \%)$ and B. isabeliae CVS- $8^{\mathrm{T}}$ (95.9\%). These similarity values are below the cut-off value of $97.0 \%$, the level normally judged sufficient to justify the proposal of a novel bacterial species (Stackebrandt \& Goebel, 1994; Janda \& Abbott, 2002). Similar results were obtained with the maximum-parsimony algorithm (Supplementary Fig. S1, available in IJSEM Online).

Analysis of respiratory quinones was carried out by the DSMZ Identification Service and Dr Brian Tindall (DSMZ, Braunschweig, Germany). Peptidoglycan analysis was performed by using the method of Schleifer \& Kandler (1972) and Schleifer (1985). Lipids were extracted and analysed according to Suresh et al. (2004). The predominant isoprenoid quinone in strain BFLP- ${ }^{\mathrm{T}}$ was unsaturated menaquinone with seven isoprene units (MK-7) and the diagnostic diamino acid in the cell wall was mesodiaminopimelic acid. Diphosphatidylglycerol, phosphatidylglycerol, phosphatidylethanolamine and an unknown aminoglycophospholipid were identified by TLC. These characteristics confirm that strain BFLP- $1^{\mathrm{T}}$ belongs to the genus Bacillus (Albert et al., 2007). 


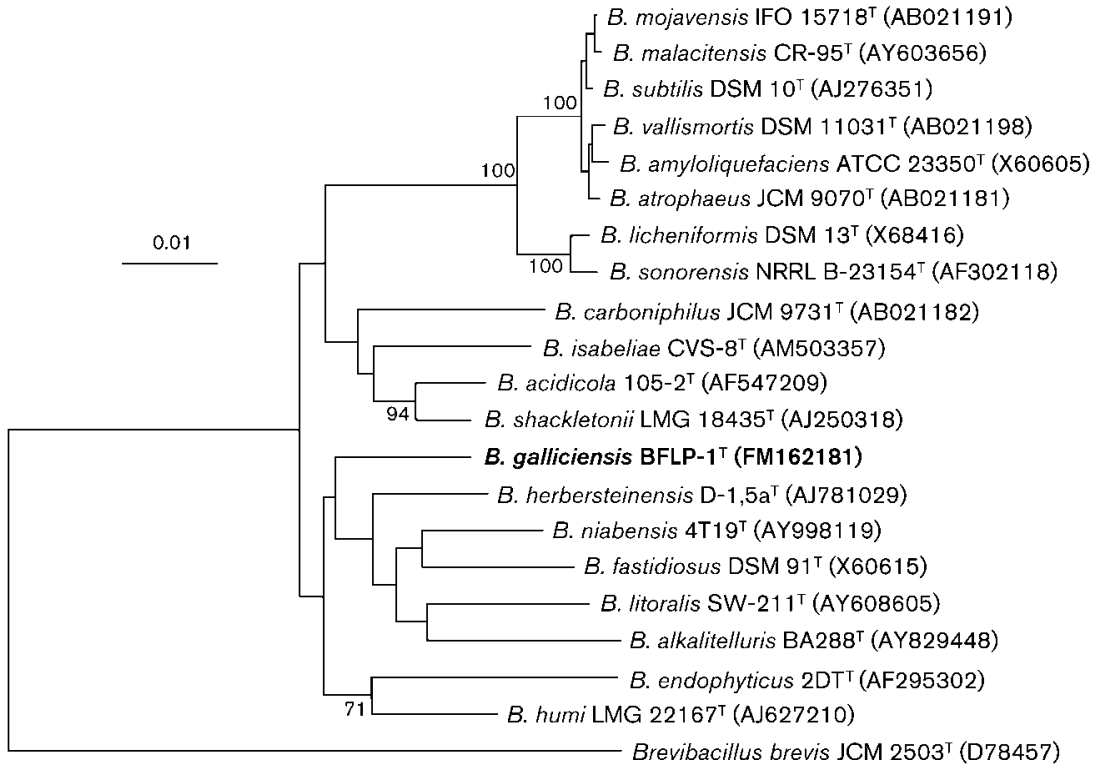

Fig. 1. Phylogenetic dendrogram of strain BFLP $-1^{\top}$ with the most closely related Bacillus strains, based on 16S rRNA gene sequences and constructed by the neighbour-joining method. Bootstrap percentages ( $>70 \%$ ) based on 1000 replications are shown at branch nodes. Brevibacillus brevis JCM $2503^{\top}$ was used as an outgroup. Bar, $1 \%$ estimated sequence divergence.
Whole-cell fatty acids from the isolate were extracted from biomass grown on nutrient agar and analysed according to the standard protocol of the Sherlock Microbial Identification System version 4.5 (MIDI). The fatty acid composition was iso- $\mathrm{C}_{14: 0}(3.1 \%), \mathrm{C}_{14: 0} \quad(1.0 \%)$, iso- $\mathrm{C}_{15: 0}(4.8 \%)$, anteiso- $\mathrm{C}_{15: 0}(62.4 \%), \mathrm{C}_{15: 0}(1.1 \%)$, $\mathrm{C}_{16: 1} \omega 7 c(1.9 \%)$, iso- $\mathrm{C}_{16: 0}(1.4 \%), \mathrm{C}_{16: 1} \omega 11 c(7.3 \%)$, $\mathrm{C}_{16: 0}(3.8 \%)$, iso- $\mathrm{C}_{17: 1} \omega 10 c(0.7 \%)$, iso- $\mathrm{C}_{17: 0}(0.7 \%)$ and anteiso- $\mathrm{C}_{17: 0}(9.0 \%)$. Thus, the major fatty acids in strain BFLP- $1^{\mathrm{T}}$ were anteiso- $\mathrm{C}_{15: 0}$, anteiso- $\mathrm{C}_{17: 0}$ and $\mathrm{C}_{16: 1} \omega 11 c$, which comprised approximately $79 \%$ of the cellular fatty acids extracted. Branched fatty acids, 14- to 17-carbon iso and anteiso series, are typically the major fatty acids found in Bacillus cell membranes (Kämpfer, 1994). However, strain BFLP $-1^{\mathrm{T}}$ and the most closely related strains, B. herbersteinensis $\mathrm{D}-1,5 \mathrm{a}^{\mathrm{T}}$, B. shackletonii $\mathrm{LMG} 18435^{\mathrm{T}}$ and $B$. isabeliae CVS $-8^{\mathrm{T}}$, could be clearly distinguished from each other based on relative fatty acid concentrations (Table 1).

Therefore, the phenotypic and genotypic properties of strain BFLP- ${ }^{\mathrm{T}}$ support its classification in a novel species within the genus Bacillus, for which the name Bacillus galliciensis sp. nov. is proposed.

\section{Description of Bacillus galliciensis sp. nov.}

Bacillus galliciensis (gal.li.ci.en'sis. L. masc. adj. galliciensis of Galicia, north-west Spain).

Cells are aerobic, Gram-positive-staining and spore-forming motile rods $(0.8-1.2 \times 2.5-3.5 \mu \mathrm{m})$. Primarily occur as single cells, although short chains are also seen. Oval spores develop subterminally in the cells and usually cause the sporangia to swell. Colonies on TSA after $48 \mathrm{~h}$ at $20{ }^{\circ} \mathrm{C}$ are cream-coloured, slightly irregular in shape and $1.5-3.0 \mathrm{~mm}$ in diameter. Optimum temperature for growth is $20{ }^{\circ} \mathrm{C}$; no growth at 5 or $35{ }^{\circ} \mathrm{C}$. Optimum $\mathrm{pH}$ for growth is $\mathrm{pH} 7.2$; grows at $\mathrm{pH} 5.5-9.0$ but not at $\mathrm{pH} 5.0$ or 9.5. Optimum $\mathrm{NaCl}$ concentration for growth is $2 \%(\mathrm{w} / \mathrm{v}) \mathrm{NaCl}$; grows with $0-7 \%(\mathrm{w} / \mathrm{v}) \mathrm{NaCl}$ but not with $8 \%(\mathrm{w} / \mathrm{v})$ $\mathrm{NaCl}$. Positive for catalase, oxidase, $\mathrm{N}$-acetylglucosamine, aesculin hydrolysis, $\beta$-galactosidase and assimilation of D-glucose, L-arabinose, D-mannitol, $N$-acetylglucosamine, maltose and potassium gluconate. Negative for indole production, nitrate production, urease, arginine dihydrolase, gelatin hydrolysis and assimilation of D-mannose, caprate, adipate, malate, citrate and phenylacetate. Acid is not produced from L-arabinose, cellobiose, D-glucose, glycerol, lactose, maltose, D-mannitol, D-mannose, melezitose, raffinose, L-rhamnose, salicin, D-sorbitol, sucrose, trehalose or D-xylose. The major fatty acids are anteiso$\mathrm{C}_{15: 0}$, anteiso- $\mathrm{C}_{17: 0}$ and $\mathrm{C}_{16: 1} \omega 11 c$; smaller amounts of iso- $\mathrm{C}_{14: 0}, \mathrm{C}_{14: 0}$, iso- $\mathrm{C}_{15: 0}, \mathrm{C}_{15: 0}$, iso- $\mathrm{C}_{16: 0}, \mathrm{C}_{16: 1} \omega 7 c$, $\mathrm{C}_{16: 0}$, iso- $\mathrm{C}_{17: 1} \omega 10 c$ and iso- $\mathrm{C}_{17: 0}$ are present. The diamino acid in the cell wall is meso-diaminopimelic acid. The major respiratory menaquinone is MK-7. The major polar lipids are diphosphatidylglycerol, phosphatidylglycerol, phosphatidylethanolamine and an unknown aminoglycophospholipid. The $\mathrm{G}+\mathrm{C}$ content of the type strain is $48.1 \mathrm{~mol} \%\left(T_{\mathrm{m}}\right)$.

The type strain, BFLP $-1^{\mathrm{T}}\left(=\mathrm{DSM} 21539^{\mathrm{T}}=\mathrm{LMG} 24668^{\mathrm{T}}\right)$, was isolated from faeces of wild seahorses captured in north-west Spain (Toralla, Galicia).

\section{Acknowledgements}

This study was financed by the Spanish Ministry of Science and Technology (Hippocampus CGL2005-05927-C03-01). J. L. B. was supported by a postdoctoral I3P contract from the Spanish Council for Scientific Research (CSIC). We thank P. Quintas, A. Chamorro, C. Soto and S. Otero for skilful technical assistance. We also thank H.-J. Busse, N. A. Logan and M. S. da Costa for providing us with $B$. herbersteinensis $\mathrm{D}-1,5 \mathrm{a}^{\mathrm{T}}$, B. shackletonii $\mathrm{LMG} 18435^{\mathrm{T}}$ and $B$. isabeliae CVS $-8^{\mathrm{T}}$, respectively. 


\section{References}

Albert, R. A., Archambault, J., Lempa, M., Hurst, B., Richardson, C., Gruenloh, S., Duran, M., Worliczek, H. L., Huber, B. E. \& other authors (2007). Proposal of Viridibacillus gen. nov. and reclassification of Bacillus arvi, Bacillus arenosi and Bacillus neidei as Viridibacillus arvi gen. nov., comb. nov., Viridibacillus arenosi comb. nov. and Viridibacillus neidei comb. nov. Int J Syst Evol Microbiol 57, 2729-2737.

Albuquerque, L., Tiago, I., Taborda, M., Nobre, M. F., Veríssimo, A. \& da Costa, M. S. (2008). Bacillus isabeliae sp. nov., a halophilic bacterium isolated from a sea salt evaporation pond. Int J Syst Evol Microbiol 58, 226-230.

Altschul, S. F., Gish, W., Miller, W., Myers, E. W. \& Lipman, D. J. (1990). Basic local alignment search tool. J Mol Biol 215, 403-410.

Ash, C., Farrow, J. A. E., Wallbanks, S. \& Collins, M. D. (1991). Phylogenetic heterogeneity of the genus Bacillus revealed by comparative analysis of small-subunit-ribosomal RNA sequences. Lett Appl Microbiol 13, 202-206.

Balcázar, J. L. \& Rojas-Luna, T. (2007). Inhibitory activity of probiotic Bacillus subtilis UTM 126 against Vibrio species confers protection against vibriosis in juvenile shrimp (Litopenaeus vannamei). Curr Microbiol 55, 409-412.

Banat, I. M., Makkar, R. S. \& Cameotra, S. S. (2000). Potential commercial applications of microbial surfactants. Appl Microbiol Biotechnol 53, 495-508.

Buck, J. D. (1982). Nonstaining (KOH) method for determination of Gram reactions of marine bacteria. Appl Environ Microbiol 44, 992993.

Chun, J. \& Goodfellow, M. (1995). A phylogenetic analysis of the genus Nocardia with 16S rRNA gene sequences. Int J Syst Bacteriol 45, 240-245.

Janda, J. M. \& Abbott, S. L. (2002). Bacterial identification for publication: when is enough enough? J Clin Microbiol 40, 1887-1891.

Kämpfer, P. (1994). Limits and possibilities of total fatty acid analysis for classification and identification of Bacillus species. Syst Appl Microbiol 17, 86-98.

Lim, J. M., Jeon, C. O., Jang, H. H., Park, D. J., Shin, Y. K., Yeo, S. H. \& Kim, C. J. (2008). Albimonas donghaensis gen. nov., sp. nov., a nonphotosynthetic member of the class Alphaproteobacteria isolated from seawater. Int J Syst Evol Microbiol 58, 282-285.

Logan, N. A., Lebbe, L., Verhelst, A., Goris, J., Forsyth, G., RodriguezDías, M., Heyndrickx, M. \& De Vos, P. (2004). Bacillus shackletonii sp. nov., from volcanic soil on Candlemas Island, South Sandwich archipelago. Int J Syst Evol Microbiol 54, 373-376.

Mandel, M. \& Marmur, J. (1968). Use of ultraviolet absorbancetemperature profile for determining the guanine plus cytosine content of DNA. Methods Enzymol 12B, 195-206.

Rössler, D., Ludwig, W., Schleifer, K. H., Lin, C., McGill, T. J., Wisotzkey, J. D., Jurtshuk, P., Jr \& Fox, G. E. (1991). Phylogenetic diversity in the genus Bacillus as seen by $16 \mathrm{~S}$ rRNA sequencing studies. Syst Appl Microbiol 14, 266-269.

Schleifer, K. H. (1985). Analysis of the chemical composition and primary structure of murein. Methods Microbiol 18, 123-156.

Schleifer, K. H. \& Kandler, O. (1972). Peptidoglycan types of bacterial cell walls and their taxonomic implications. Bacteriol Rev 36, 407477.

Sorokulova, I. B., Pinchuk, I. V., Denayrolles, M., Osipova, I. G., Huang, J. M., Cutting, S. M. \& Urdaci, M. C. (2008). The safety of two Bacillus probiotic strains for human use. Dig Dis Sci 53, 954-963.

Stackebrandt, E. \& Goebel, B. M. (1994). Taxonomic note: a place for DNA-DNA reassociation and 16S rRNA sequence analysis in the present species definition in bacteriology. Int J Syst Bacteriol 44, 846849.

Suresh, K., Reddy, G. S. N., Sengupta, S. \& Shivaji, S. (2004). Deinococcus indicus sp. nov., an arsenic-resistant bacterium from an aquifer in West Bengal, India. Int J Syst Evol Microbiol 54, 457461 .

Tamura, K., Dudley, J., Nei, M. \& Kumar, S. (2007). MEGA4: molecular evolutionary genetics analysis (MEGA) software version 4.0. Mol Biol Evol 24, 1596-1599.

Thompson, J. D., Gibson, T. J., Plewniak, F., Jeanmougin, F. \& Higgins, D. G. (1997). The CLUSTAL_X windows interface: flexible strategies for multiple sequence alignment aided by quality analysis tools. Nucleic Acids Res 25, 4876-4882.

Wieser, M., Worliczek, H., Kämpfer, P. \& Busse, H.-J. (2005). Bacillus herbersteinensis sp. nov. Int J Syst Evol Microbiol 55, 2119-2123.

Xu, D. \& Côté, J.-C. (2003). Phylogenetic relationships between Bacillus species and related genera inferred from comparison of $3^{\prime}$ end $16 \mathrm{~S}$ rDNA and $5^{\prime}$ end 16S-23S ITS nucleotide sequences. Int J Syst Evol Microbiol 53, 695-704.

Xue, Y., Ventosa, A., Wang, X., Ren, P., Zhou, P. \& Ma, Y. (2008). Bacillus aidingensis sp. nov., a moderately halophilic bacterium isolated from Ai-Ding salt lake in China. Int J Syst Evol Microbiol 58, $2828-2832$. 